\title{
Marcos Urcola
}

Lic. en Trabajo Social (UNR)

Dr. en Antropología (UNR)

Investigador de CONICET

E-mail:murcola@hotmail.com

\section{Eric Hobsbawm}

Cómo cambiar el mundo: Marx y el marxismo 1840-2011

Buenos Aires: Crítica, 2011

490 páginas | ISBN 9789879317266

"Una vez más, ha llegado la hora de tomarse en serio a Marx" (p. 424). Con esta frase, el historiador marxista Eric Hobsbawm, nos invita a hacer un repaso por la obra del pensador más importante del siglo XX y, por qué no, del insipiente siglo XXI. El autor afirma que para resolver los problemas a los que se enfrenta el mundo actual, no pueden eludirse las preguntas de Karl Marx acerca del desarrollo económico capitalista, los procesos de concentración, globalización, crisis y cambio que este conlleva, las luchas de clases entre "los que pagan el salario y los que lo reciben" y sobre los posibles cursos del devenir histórico de la humanidad.

En la actualidad, la crisis financiera del 2008 ha operado, a su criterio, como "una especie de equivalente de derechas de la caída del muro de Berlín" ( $p$. 420). El "mercado" no tiene respuestas al principal problema al que se enfrenta este siglo: que el ilimitado crecimiento económico, cada vez más altamente tecnológico y en busca de beneficios insostenibles, produce riqueza global, pero a costa de la prescindibilidad del trabajo humano como factor de producción y en detrimento de los recursos naturales del planeta. El crack económico de 2008 ha puesto en evidencia el hecho de que el capitalismo no es la respuesta o la única respuesta, sino "la gran pregunta". Y en este aspecto es donde se hacen fuertes el pensamiento y la obra de Marx. Su visión sobre el capitalismo como una moda- 
lidad histórica temporal de la economía humana y su análisis del modus operandi de éste, siempre en expansión y concentración, generando crisis y autotransformándose, nunca ha perdido vigencia. El mundo capitalista globalizado que surgió en la década de 1990 fue en aspectos cruciales muy parecido al mundo anticipado por él en el Manifiesto comunista y el fin del marxismo oficial de la URSS liberó a Marx de la teoría y práctica leninista, permitiendo divisar todas las cosas que aún podía decir sobre nuestro mundo actual.

Hobsbawm plantea que nuestros juicios sobre el marxismo del siglo XX no se sustentaron en el pensamiento de Marx, sino en interpretaciones o revisiones de su obra: "Desde el momento en que cualquier conjunto de ideas sobrevive a su creador, cesa de estar confinado a sus intenciones y contenidos originales. Dentro de los amplios límites establecidos por la capacidad humana de exégesis (...) dicho conjunto de ideas está sujeto a un amplio e impredecible abanico de modificaciones y transformaciones prácticas y teóricas" (p. 350). Por ello, Cómo cambiar el mundo es un estudio que pretende transmitir el impacto y desarrollo póstumo del pensamiento de Karl Marx (y el inseparable Frederick Engels). A casi 130 años de su muerte, no se ha consolidado como predominante ninguna versión del marxismo replanteado o modificado. Con esto, no quiere decir que haya una aguda diferencia entre marxismos "correctos" e "incorrectos", sino que su forma de investigar podía y puede aún hoy producir diferentes resultados y perspectivas políticas. Y de ahí la riqueza del cuerpo teórico que conforma la obra que el autor pretende rescatar.

El libro está compuesto por una recopilación de trabajos relativos al estudio de la obra de Marx y del marxismo que el autor realizó entre los años 1956 y 2009. En el mismo se incluyen ensayos, conferencias y charlas adaptados para esta edición, seis capítulos que forman parte de los cuatro volúmenes que integran la Storia del Marxismo publicado en Italia por la editorial Einaudi (1979-1982) y tres escritos publicados como introducciones a obras específicas: La situación de la clase obrara en Inglaterra de Engels, El manifiesto comunista de Marx y Engels y los manuscritos de Marx sobre las formaciones económicas precapitalistas conocidos como Grundrisse.

El libro se divide en dos grande partes. La primera, titulada "Marx y Engels", ofrece una serie de textos donde se desarrolla la importancia de las obras concretas de los autores. El contexto en el que surgieron, cuáles eran las inquietudes y motivaciones de los autores cuando las produjeron, el impacto que tuvieron mientras los mismos estaban vivos y los procesos de revisión, ampliación y cambio que las mismas tuvieron en los tiempos posteriores a su fallecimiento: cuáles fueron las obras publicadas en vida por ambos autores (La sagrada familia, El manifiesto comunista, Las luchas de clases en Francia, El dieciocho Brumario de Luis Bonaparte, El Capital Vol. I, etc.), cuáles fueron publicadas después de la muerte de Marx pero con Engels aún vivo (El capital, Vol. II y III) y cuáles fue- 
ron publicadas como manuscritos inéditos una vez fallecidos ambos autores ( $L a$ ideología alemana, Los manuscritos político-económicos, Grundrisse). Dentro de esta primera parte, merece especial mención el trabajo dedicado a identificar las ideas socialistas premarxianas que influyeron en el pensamiento de los autores (como las de los "socialistas utópicos" franceses Saint-Simon, Charles Fournier y Robert Owen) o con las cuales polemizaron (como es el caso de Proudhon); y el escrito sobre las ideas políticas de Marx y Engels que dieron lugar a múltiples debates a lo largo del siglo XX (sus ideas sobre el Estado y los procesos de transición del capitalismo hacia el socialismo, la lucha de clases, la revolución y su carácter internacional, los modos de organización postcapitalistas, etc.).

La otra parte del libro se titula "Marxismo" y contiene una serie de capítulos que constituyen una especie de historia del marxismo, el comunismo y el movimiento obrero entre los años 1880 y 2000 (La influencia del marxismo 1880-1914; La era del antifascismo 1929-1945; La influencia del marxismo 1945-1983 y El marxismo en recesión 1983-2000). En éstos se destacan las tensiones entre los postulados marxistas y su difusión y asimilación por parte de los movimientos sindicales y partidos políticos de base obrera (reformistas o revolucionarios), el impacto de la revolución Rusa y la posterior dogmatización de su pensamiento en el marco de la URSS, la tregua entre marxistas y no marxistas ante los avances del movimiento fascista, su penetración en el campo académico, científico e intelectual en general, los intentos de reformulación y renovación teórica de la "generación del '68", su influencia en los movimientos revolucionarios de los denominados países del "tercer mundo" y el proceso de crisis del marxismo tras el derrumbe de la Unión Soviética y la caída del muro de Berlín.

El único marxista posterior a Marx al que le dedica un par de capítulos es a Antonio Gramsci. Del mismo destaca su absoluta originalidad en el desarrollo de una teoría marxista de la política. Como bien se encarga de señalar a lo largo del libro, la dimensión política de los procesos de cambio social es fundamental para la teoría marxista y para las acciones colectivas inspiradas en la misma. Si bien Marx y Engels han escrito mucho sobre política, fueron reacios a desarrollar una teoría general sobre este campo y por ello la importancia de rescatar al autor italiano como uno de los pensadores que ha podido dar continuidad al pensamiento marxista desde este punto de vista.

Hobsbawm encuentra particular interés en la trascendencia política de la obra de Marx y en su persistencia histórica: "Si algún pensador dejó una importante e indeleble huella en el siglo XX, ése fue él” (p. 14). Pasado largamente el centenario de su muerte, ha sobrevivido a más de un siglo de fuego concentrado contra sus ideas por parte de "cualquiera que tuviera a mano una pluma, una máquina de escribir, una tribuna pública o -en algunos casos- el lápiz del censor y la imparcialidad de la policía" (p. 352). El repaso por la obra de Marx sorprende no tanto por el carácter acabado e inequívoco de su cuerpo de ideas y conceptos, 
sino por la lucidez con la que nos transmite su modo de comprensión del devenir de la historia y la vida humana, invitándonos a imaginar y proyectar (siempre con los pies sobre la tierra) otros mundos posibles. La naturaleza universal de su pensamiento, como filósofo, economista, historiador, analista político y como padre fundador (junto con Emile Durkheim y Max Weber) del pensamiento moderno sobre la sociedad, lo constituyen en un referente imprescindible para reflexionar sobre el tiempo actual y sus problemáticas. 